\title{
Improvement of lipid profile in Type 2 (non-insulin-dependent) diabetes mellitus by insulin-like growth factor I
}

\author{
P.D.Zenobi ${ }^{1}$, P.Holzmann ${ }^{1}$, Y. Glatz ${ }^{1}$,W.F. Riesen ${ }^{2}$ and E. R.Froesch ${ }^{1}$ \\ ${ }^{1}$ Division of Endocrinology and Metabolism, Department of Internal Medicine, University Hospital, Zurich, Switzerland \\ ${ }^{2}$ Institute of Clinical Chemistry and Haematology, State Hospital, St. Gallen, Switzerland
}

\begin{abstract}
Summary. Type 2 (non-insulin-dependent) diabetes mellitus is associated with increased glucose, insulin, total and VLDLtriglyceride, and often total and LDL-cholesterol levels which promote vascular disease. Recombinant human insulin-like growth factor-I which mimics many effects of insulin, decreased insulin, total and VLDL-triglyceride, and total and LDL-cholesterol levels in healthy man as well as glucose and insulin levels in Type 2 diabetic patients. We, therefore, investigated total and fractionated triglyceride and cholesterol levels, lipoprotein(a), non-esterified fatty acid, and apolipoprotein levels in eight Type 2 diabetic patients during five control, five treatment, and three wash-out days. They received a constant diet throughout and daily $2 \times 120 \mu \mathrm{g}$ insulin-like growth factor- $\mathrm{I} / \mathrm{kg}$ s.c. during the treatment period. Fasting total and VLDL-triglyceride, total and LDL-cholesterol control lev-
\end{abstract}

els were (mean $\pm \mathrm{SD}$ ) $3.1 \pm 2.6,1.3 \pm 1.0,6.3 \pm 1.3$, and $4.5 \pm 1.1 \mathrm{mmol} / 1$ and decreased to $1.6 \pm 0.8,0.6 \pm 0.4,5.0 \pm 1.0$, and $3.5 \pm 1.1 \mathrm{mmol} / \mathrm{l}$, respectively, on the last treatment day $(p<0.01)$. During therapy, fasting lipoprotein(a) levels and the postprandial area under the triglyceride curve decreased by $48 \pm 22$ and $32 \pm 18 \%$ of control $(p<0.01)$, respectively. In conclusion, insulin-like growth factor-I lowered lipid levels in Type 2 diabetic patients directly or indirectly or both because of decreased glucose and insulin levels. Long-term trials would be of interest with respect to the cardiovascular risk in Type 2 diabetes and patients with hyperlipidaemia.

Key words: Insulin-like growth factor-I, insulin-like growth factor-II, Type 2 (non-insulin-dependent) diabetes mellitus, insulin resistance, triglyceride, cholesterol, lipoprotein(a).
Type 2 (non-insulin-dependent) diabetes mellitus is associated with an increased morbidity and mortality from cardiovascular disease $[1,2]$. Known risk factors in Type 2 diabetes are hypertension, hyperglycaemia, obesity, elevated total and VLDL-triglycerides (TG), low HDL-cholesterol (C) levels, and, less consistently, increased total and LDL-C levels $[1,2]$. Hyperinsulinaemia was also claimed to be atherogenic in some but not in all studies [3]. Lipoprotein(a) $[\mathrm{Lp}(\mathrm{a})]$ is another strong and independent risk factor in non-diabetic man [4]. Conclusive results in diabetic patients are not yet available.

Weight loss as the most reasonable therapeutic approach in Type 2 diabetic patients diminishes hypertension as well as glucose, insulin, TG, total C, and non-esterified fatty acid (NEFA) levels and increases HDL-C levels $[5,6]$. Sulphonylureas and insulin can lower glucose and TG levels markedly but do not clearly decrease total and LDL-C and increase HDL-C levels, respectively [7-11]. Insulin administration did not result in a decrease of $L p(a)$ levels in Type 2 diabetic patients [9]. In contrast, sulphonylureas and insulin enhance hyperinsulinaemia [11] and may, thereby, worsen the atherogenic risk $[3,6]$.
Insulin-like growth factor-I (IGF-I) is a physiological growth-promoting and cell-differentiation enhancing factor. It also mimics many effects of insulin $[12,13]$. These effects are mediated via the type 1 IGF or the insulin receptor on muscle cells or both [13] and the insulin receptor on adipocytes and hepatocytes which lack specific type 1 IGF receptors $[12,14]$. We reported that recombinant human (rh)IGF-I decreased insulin, C-peptide, total and VLDL-TG, and total and LDL-C levels in healthy volunteers without affecting HDL-C levels $[15,16]$. More recently, we showed that rhIGF-I lowered glucose and insulin levels in Type 2 diabetic patients [17]. Thus, rhIGF-I may diminish the increased cardiovascular risk of Type 2 diabetes by normalizing hyperglycaemia, hyperinsulinaemia, and by lowering lipid levels.

\section{Subjects and methods}

\section{Subjects}

Six male and two female otherwise healthy patients with Type 2 diabetes gave informed and written consent to participate in this study. Their clinical characteristics are described elsewhere [17]. In 
Table 1. Total triglyceride levels (mmol/1) during meal tolerance test before (day 4-5), during (day 8-10), and following (day 11, 12) recombinant human insulin-like growth factor-I administration

\begin{tabular}{lllll}
\hline Time & Day 4-5 & Day 8-10 & Day 11 & Day 12 \\
\hline 08.00 & $2.9 \pm 2.7$ & $1.7 \pm 1.1^{\mathrm{a}}$ & $1.7 \pm 0.7^{\mathrm{a}}$ & $1.8 \pm 0.5$ \\
08.30 & $3.1 \pm 2.9$ & $1.8 \pm 1.2^{\mathrm{a}}$ & $1.6 \pm 0.9^{\mathrm{b}}$ & $1.9 \pm 0.5$ \\
09.00 & $3.2 \pm 2.8$ & $1.8 \pm 1.0^{\mathrm{a}}$ & $1.9 \pm 0.7^{\mathrm{a}}$ & $2.0 \pm 0.5$ \\
10.00 & $3.6 \pm 2.6$ & $2.1 \pm 1.1^{\mathrm{a}}$ & $2.2 \pm 0.8^{\mathrm{a}}$ & $2.3 \pm 0.8$ \\
11.00 & $3.9 \pm 2.9$ & $2.4 \pm 1.2^{\mathrm{a}}$ & $2.5 \pm 0.9^{\mathrm{b}}$ & $2.6 \pm 1.0$ \\
12.00 & $3.8 \pm 3.1$ & $2.5 \pm 1.2^{\mathrm{b}}$ & $2.5 \pm 0.9$ & $2.6 \pm 1.1$ \\
\hline
\end{tabular}

${ }^{\mathrm{a}} p<0.01,{ }^{\mathrm{b}} p<0.02$ vs day $4-5$

brief, the mean ( $\pm \mathrm{SD}$ ) age was $48 \pm 8$ years (range $38-60$ years), the body mass index was $26 \pm 3 \mathrm{~kg} / \mathrm{m}^{2}\left(23-33 \mathrm{~kg} / \mathrm{m}^{2}\right)$, diabetes was known for $7 \pm 5$ years $(0.5-14$ years $)$, and $\mathrm{HbA}_{1 \mathrm{c}}$ was $8.0 \pm 2.2 \%$ (5.8-11.0\%; normal 4.6-6.4\%). The patients' weight was constant prior to the study. Six patients were treated with glibenclamide and diet, two with diet alone.

A dietary history served to calculate the diet which the patients received during the study. The ethics committee of the Department of Internal Medicine of the University Hospital at Zurich approved the protocol which has previously been reported [17].

\section{Experimental protocol}

The patients taking glibenclamide discontinued the drug 3 days before the study during which the patients received a sucrose-free diet of $30 \mathrm{kcal} / \mathrm{kg}$ body weight throughout $(50 \%$ carbohydrates, $20 \%$ protein, $30 \%$ fat containing $18 \%$ polyunsaturated fatty acids and $360 \mathrm{mg}$ cholesterol, and $37 \mathrm{~g}$ fibres). This composition did not markedly differ from the usual diet of the study subjects. The study started with control days $1-5$, was followed by the rhIGF-I treatment (days 6-10), and concluded with the wash-out days 11-13. RhIGF-I was kindly provided by Ciba-Geigy AG (Basel, Switzerland) and on days 6-10,120 $\mu \mathrm{g}$ rhIGF-I/kg body weight was injected s. c. into the thigh two times daily (at 07.00 and 18.30 hours), except for day 10 when the injection at 18.30 hours was omitted. RhIGF-I administration was well tolerated, did not change body weight, and increased total and "free" IGF-I levels 5.3 and 2.5 times above control levels, respectively, while fasting and postprandial glucose, insulin, C-peptide, proinsulin, total IGF-II, and growth hormone levels decreased markedly [17].

After a light meal at 21.30 hours to avoid nocturnal hypoglycaemia (fruit with $12 \pm 2 \mathrm{~g}$ carbohydrates and $0.3 \pm 0.1 \mathrm{~g}$ fat) and a subsequent fast for 10.5 hours, blood was drawn every morning except on days 2 and 3 to determine lipid, apolipoprotein, and NEFA levels. A meal tolerance test was performed on day 4, 5, and 8-12. On these days a standard breakfast and the 10.00 hour light meal were eaten together between 08.00 and 08.30 hours and blood samples were drawn at the times indicated (Table 1). The breakfast and light meal with the same composition as the diet described above consisted of $87 \pm 11 \mathrm{~g}$ carbohydrates $(1.2 \mathrm{~g} / \mathrm{kg})$ and $29 \pm 7 \mathrm{~g}$ fat $(0.25 \mathrm{~g} / \mathrm{kg})$.

\section{Analytical methods}

Venous blood was allowed to clot before centrifugation, the overlying serum decanted and stored in aliquots at $-20^{\circ} \mathrm{C}$ until assayed. $150 \mu \mathrm{l}$ serum were ultracentrifuged at $140000 \mathrm{~g}$ for $150 \mathrm{~min}$ at room temperature and VLDL-TG were determined in the overlying $40 \mu \mathrm{l}$. HDL was separated from the infranatant by phosphoric wolfram acid precipitation. $\mathrm{HDL}_{3}$ was determined as described previously [18]. Total serum and fractionated lipoprotein TG and Clevels were measured with kits (Boehringer Mannheim GmbH, Mannheim,
FRG). Lp(a) and NEFA levels were determined with RIA (Pharmacia AB, Uppsala, Sweden) and as described [12], respectively. Apolipoprotein $\mathrm{AI}(\mathrm{apo} \mathrm{AI})$ and $\mathrm{B}(\mathrm{apoB})$ serum levels were measured by turbidimetric immunoprecipitation assay kits on a Cobas Mira random access analyser (Roche, Basel, Switzerland).

\section{Statistical analysis}

All data are presented as mean $\pm \mathrm{SD}$. $\mathrm{HDL}_{2}$-Clevels were calculated by subtracting $\mathrm{HDL}_{3}-\mathrm{C}$ from HDL-C. The results were analysed using the two-tailed Wilcoxon's matched pairs signed rank test. Areas under the curve (AUC) and linear regressions were calculated using the trapezoidal rule and the method of least squares, respectively. A $p$ value of less than 0.05 was considered significant.

\section{Results}

Fasting total and VLDL-TG levels were elevated during the control days, decreased during rhIGF-I treatment to a nadir of $1.6 \pm 0.8$ and $0.61 \pm 0.4 \mathrm{mmol} / \mathrm{l}$, respectively on day 10 and changed very little thereafter (Fig.1). Total and VLDL-TG levels correlated well throughout $(r=0.95)$. The decrease of VLDL-TG levels accounted for $52 \pm 15 \%$ of the fall of total TG between days 6 to 8 , suggesting that a reduced VLDL production was the

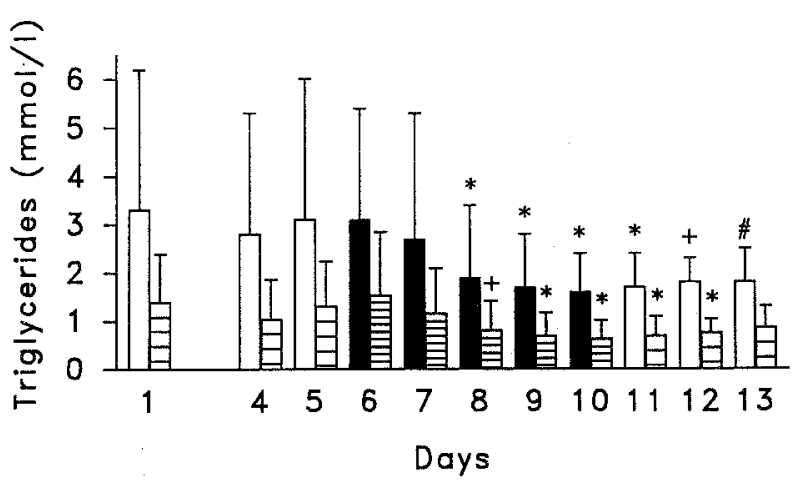

Fig. 1. Total (left bar) and VLDL-TG (right bar) levels (mean \pm SD, $n=8$ ) are shown before (day $1-5$; open and coarsely hatched), during (day 6-10; solid and fine hatched), and following (day 11-13; open and coarsely hatched) rhIGF-I administration. ${ }^{*} p<0.01,{ }^{+} p<0.02$, ${ }^{\sharp} p<0.05$ vs control levels

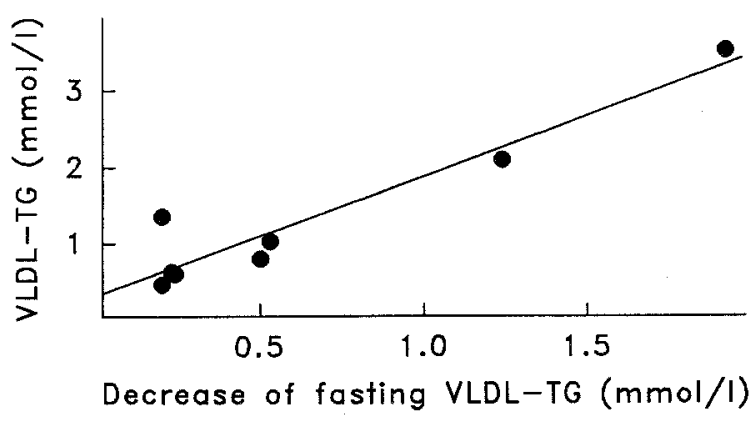

Fig. 2. Decrease of fasting VLDL-TG levels during rhIGF-I treatment vs control levels. The differences between the mean fasting VLDL-TG levels during the control and the treatment period are correlated with the fasting VLDL-TG levels during the control period $(y=1.57 x+0.32, r=0.950, p<0.001)$. Each circle represents the value of one subject 
Table 2. $\mathrm{AUC}_{\mathrm{TG}}, \mathrm{iAUC}_{\mathrm{TG}}$, and $\mathrm{AUC}_{\mathrm{NEFA}}$ during meal tolerance test before (day 4-5), during (day 8-10), and following (day 11, 12) recombinant human insulin-like growth factor-I administration

\begin{tabular}{lclll}
\hline & Day 4-5 & Day 8-10 & Day 11 & Day 12 \\
\hline AUC $_{\mathrm{TG}}(\mathrm{mmol} / \mathrm{l} \cdot \mathrm{h})$ & $14.1 \pm 11.0$ & $8.5 \pm 4.5^{\mathrm{a}}$ & $8.6 \pm 3.1^{\mathrm{a}}$ & $9.2 \pm 2.9$ \\
iAUC $_{\mathrm{TG}}(\mathrm{mmol} / \mathrm{l} \cdot \mathrm{h})$ & $2.3 \pm 0.9$ & $1.7 \pm 0.9^{\mathrm{b}}$ & $1.8 \pm 1.0$ & $1.9 \pm 1.7$ \\
AUC $_{\text {NEFA }}(\mathrm{mmol} / \mathrm{h} \cdot \mathrm{h})$ & $1.7 \pm 0.7$ & $1.5 \pm 0.5$ & $1.3 \pm 0.3$ & $1.4 \pm 0.2$ \\
\hline
\end{tabular}

${ }^{\mathrm{a}} p<0.01,{ }^{\mathrm{b}} p<0.02$ vs day $4-5$

$\mathrm{AUC}_{\mathrm{TG}}$, Area under the triglyceride curve; $\mathrm{iAUC}_{\mathrm{TG}}$, incremental area under the triglyceride curve; $\mathrm{AUC}_{\mathrm{NEFA}}$, area under the non-esterified fatty acid curve

Table 3. $\mathrm{HDL}_{2}$ and $\mathrm{HDL}_{3}$-cholesterol levels before (day 4-5), during (day 8-10), and following (day 11-13) recombinant human insulin-like growth factor-I administration

\begin{tabular}{cll}
\hline Day & $\mathrm{HDL}_{2} \mathrm{C}(\mathrm{mmol} / \mathrm{l})$ & $\mathrm{HDL}_{3}{ }^{-} \mathrm{C}(\mathrm{mmol} / 1)$ \\
\hline 4 & $0.17 \pm 0.24$ & $0.58 \pm 0.18$ \\
5 & $0.17 \pm 0.21$ & $0.52 \pm 0.12$ \\
8 & $0.22 \pm 0.23$ & $0.42 \pm 0.12^{\mathrm{a}}$ \\
9 & $0.18 \pm 0.14$ & $0.46 \pm 0.14^{\mathrm{a}}$ \\
10 & $0.20 \pm 0.13$ & $0.43 \pm 0.13^{\mathrm{c}}$ \\
11 & $0.21 \pm 0.19^{\mathrm{c}}$ & $0.41 \pm 0.14^{\mathrm{b}}$ \\
12 & $0.15 \pm 0.21$ & $0.49 \pm 0.18$ \\
13 & $0.31 \pm 0.19$ & $0.46 \pm 0.17$ \\
\hline
\end{tabular}

${ }^{\mathrm{a}} p<0.01,{ }^{\mathrm{b}} p<0.02,{ }^{\mathrm{c}} p<0.05$ vs day $4-5$

$\mathrm{HDL}_{2}$, High density lipoprotein ${ }_{2} \mathrm{HDL}_{3}$ high density lipoprotein ${ }_{3}$; C, cholesterol

Table 4. ApoAI and apoB levels before (day 4-5), during (day 8-10), and following (day 11-13) recombinant human insulin-like growth factor-I administration

\begin{tabular}{cll}
\hline Day & apoAI $(\mathrm{g} / \mathrm{l})$ & apoB $(\mathrm{g} / 1)$ \\
\hline 4 & $1.28 \pm 0.15$ & $1.31 \pm 0.17$ \\
5 & $1.32 \pm 0.31$ & $1.33 \pm 0.16$ \\
8 & $1.28 \pm 0.14$ & $1.40 \pm 0.40$ \\
9 & $1.20 \pm 0.32$ & $1.27 \pm 0.47$ \\
10 & $1.18 \pm 0.20$ & $1.23 \pm 0.39$ \\
11 & $1.23 \pm 0.28$ & $1.18 \pm 0.29$ \\
12 & $1.26 \pm 0.32$ & $1.25 \pm 0.38$ \\
13 & $1.36 \pm 0.20$ & $1.25 \pm 0.29$ \\
\hline
\end{tabular}

ApoAI, Apolipoprotein AI; apoB, apolipoprotein B

major cause of the decrease of total TG levels during rhIGF-I administration. The decrease of VLDL-TG levels during rhIGF-I treatment correlated with the levels before treatment (Fig.2) even if the data pair of the patient with clearly increased fasting VLDL-TG levels was excluded from statistical analysis $(r=0.828, p<0.025)$. This indicates that rhIGF-I has a more pronounced effect in the subjects with higher starting VLDL-TG levels as has already been shown for glucose, insulin, and total TG levels [17]. Postprandial total TG levels (Table 1), the total and the incremental AUC for total TG (Table 2) were lower during the treatment period than in the control period. The decrease of the $\mathrm{AUG}_{\mathrm{TG}}$ during rhIGF-I administration correlated with that during the control peri$\operatorname{od}(r=0.966, p<0.001)$.

Fasting total and LDL-C levels did not change during the control period, fell during rhIGF-I treatment to a nadir of $4.83 \pm 0.92$ and $3.33 \pm 1.01 \mathrm{mmol} / \mathrm{l}$, respectively, on day 11, and remained low until day 13 (Fig.3). Total and LDL-Clevels changed proportionately $(r=0.83)$. The fall of total $\mathrm{C}$ levels between day 6 and 10 was mostly $(66 \pm 27 \%)$ due to the decrease of LDL-C. HDL-C levels hardly changed during rhIGF-I treatment (Fig. 3). Consequently, the ratios of total C to HDL-C and of LDL-C to HDL-C were $6.5 \pm 1.8$ and $4.6 \pm 1.5$ during control days and decreased during rhIGF-I treatment to $5.4 \pm 1.0$ $(p<0.02)$ and $3.8 \pm 1.0 \quad(p<0.02)$, respectively. Small changes of HDL-C levels resulted from a decrease of $\mathrm{HDL}_{3}-\mathrm{C}$ and a slightly smaller increase of $\mathrm{HDL}_{2}-\mathrm{C}$ levels (Table 3).

Lp(a) levels ( $20.7 \pm 24.7 \mathrm{mg} / \mathrm{dl}$; mean \pm SD of day $1-6)$ decreased in every patient during rhIGF-I administration to a nadir of $13.7 \pm 17.8 \mathrm{mg} / \mathrm{dl}$ on day 11 (Fig. 4 ). The individual maximal decrease was $48 \pm 22 \%$ of initial levels (range $26-93 \%$ ) and the decrease in absolute terms was more marked in those subjects with higher levels during the control period.

ApoAI and apoB serum levels remained constant during the treatment period (Table 4).

NEFA levels $(712 \pm 261 \mu \mathrm{mol} / \mathrm{l}$ on days $1-5)$ decreased insignificantly during the treatment and wash-out period to $583 \pm 243$ and $511 \pm 210 \mu \mathrm{mol} / 1$, respectively. Postprandial levels (not shown) and the AUC for NEFA $\left(\mathrm{AUC}_{\mathrm{NEFA}}\right)$ were not markedly affected by rhIGF-I treatment (Table 2).

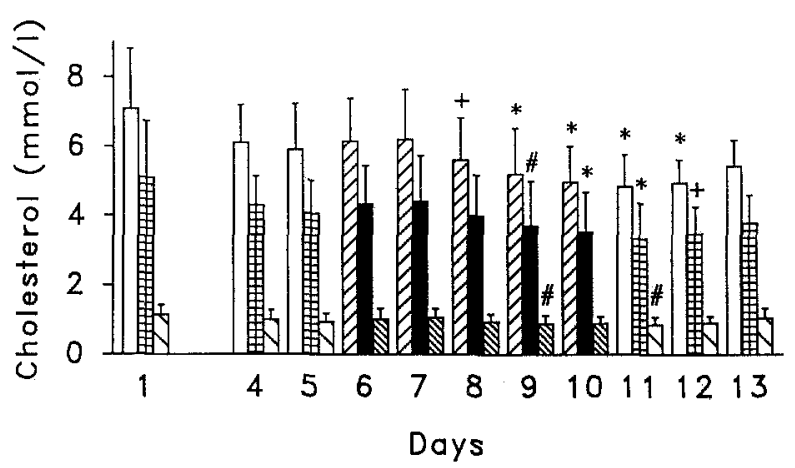

Fig. 3. Total (left bar), LDL- (middle bar), and HDL-cholesterol (right bar) levels (mean $\pm \mathrm{SD}, n=8$ ) are shown before (day $1-5$; open, cross-hatched, coarsely hatched bars), during (day 6-10; coarsely hatched, solid, fine hatched bars), and following (day 11-13; open, cross-hatched, coarsely hatched bars) rhIGF-I administration. ${ }^{*} p<0.01,{ }^{+} p<0.02,{ }^{*} p<0.05$ vs control levels

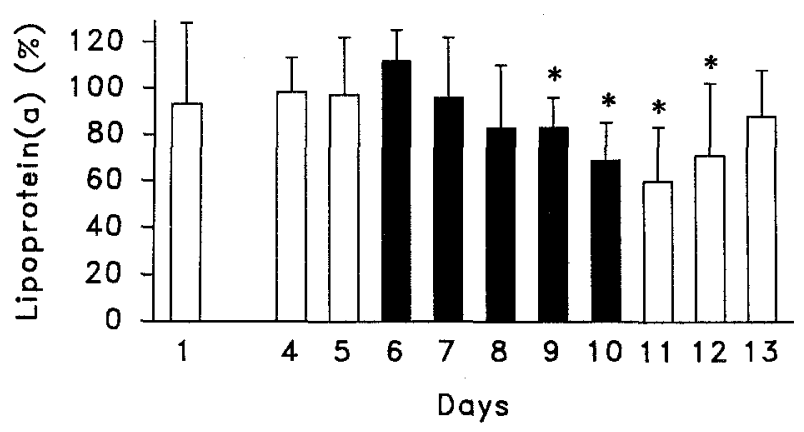

Fig. 4. Lipoprotein(a) levels (mean \pm SD in \% of mean control levels of day 1-6, $n=8$ ) are shown before (day 1-5; open bars), during (day 6-10; solid bars), and following (day 11-13; open bars) rhIGF-I administration. ${ }^{*} p<0.01$ vs control levels 


\section{Discussion}

Hypertriglyceridaemia is a frequent finding in Type 2 diabetes and is due to an increased hepatic VLDL production because of increased NEFA, glucose, and insulin levels $[10,19]$. In addition, a defect of VLDL clearance has been postulated [10]. Normalization of hyperglycaemia causes a fall of VLDL- and total TG levels [7-10].

In normal subjects rhIGF-I lowered total and VLDLTG levels [15] while glucose levels did not change but insulin and C-peptide levels clearly decreased [16]. In Type 2 diabetic patients rhIGF-I caused a near-normalization of fasting and postprandial plasma glucose levels at clearly decreased insulin and C-peptide levels [17]. In the present study we describe the effects of rhIGF-I on lipid levels.

Total and VLDL-TG levels were significantly decreased during rhIGF-I administration, presumably because of diminished VLDL production. Several mechanisms must be considered such as (1) near-normalization of hyperglycaemia, (2) a marked decrease of insulin secretion, (3) an apparent increase of insulin sensitivity, and (4) suppressed growth hormone levels [17]. NEFA levels were not lower in this study and in diabetic rats during rhIGF-I administration [20] and, therefore, probably did not contribute to the reduction of VLDL production [10]. On the other hand, IGF-I may directly stimulate glucose disposal via type 1 IGF receptors (mostly on muscle cells) [13], thereby lowering plasma glucose levels [17] and resulting in reduced VLDL production [10]. It is unlikely that IGF-I directly affects hepatic TG synthesis because hepatocytes lack type 1 IGF receptors [14]. Moreover, free IGF-I levels attained in this study [17] are not high enough to cross-react with hepatic insulin receptors. During rhIGF-I treatment free IGF-I levels are slightly increased and insulin levels markedly decreased resulting in a diminished occupancy of hepatic insulin receptors.

Whether or not IGF-I may have also improved VLDLTG clearance is not known. RhIGF-I administration in Type 2 diabetes improves metabolic control and probably insulin sensitivity [17] so that lipoprotein lipase (LPL) activity may have been stimulated [21]. The present results do not support a stimulatory effect of IGF-I on LPL. The disappearance rate of total TG after a meal in Type 2 diabetic patients was not increased as in an earlier study in healthy volunteers (unpublished data).

RhIGF-I administration may lower total and LDL-C levels due to a considerably decreased VLDL production rate. Assuming no change of the conversion rate of VLDL to LDL particles, a lower number of VLDL will necessarily result in a reduction of LDL particles. Unchanged apolipoprotein levels rather suggest a change of the lipid content than of the number of lipoproteins during rhIGF-I treatment.

Whether or not the synthesis of $\mathrm{C}$ was directly influenced by rhIGF-I is not known. Insulin stimulates the activity of HMGCoA-reductase in vitro [22]. The activity of this rate-limiting enzyme for C synthesis may thus be reduced at low insulin levels during rhIGF-I administration if these in vitro findings are of any relevance in vivo.
HDL-C levels decreased during rhIGF-I administration to such a small extent that the ratios of total $\mathrm{C}$ to HDL-C and that of LDL-C to HDL-C decreased significantly. The decrease of HDL-C levels was mostly accounted for by a fall of $\mathrm{HDL}_{3}-\mathrm{C}$ levels and a relatively smaller rise of $\mathrm{HDL}_{2}-\mathrm{C}$ levels. This shift from $\mathrm{HDL}_{3}-\mathrm{C}$ to $\mathrm{HDL}_{2}$-C may improve the cardiovascular risk [23].

RhIGF-I decreased Lp(a) levels, an affect that was not observed in insulin-treated Type 2 diabetic patients during improved metabolic control [9]. In this study, Lp(a) levels decreased within $4-6$ days by $48 \pm 22 \%$ of control (range 26-93\%) and this effect was more pronounced in those patients with higher starting Lp(a) levels. Only HELP-LDL-apheresis [24] decreased Lp(a) levels so much in such a short time. Since the nadir Lp(a) levels in this study were reached in most patients on the last treatment or the first wash-out day, longer rhIGF-I administration might have decreased $L p(a)$ levels even further. This may even hold true for other lipid levels considering the long half-life of lipoproteins. The decrease of $L p(a)$ may also be related to the suppression of growth hormone secretion [25] by rhIGF-I administration [16, 17].

It would have been preferable to randomize the control and treatment period of this study to avoid a possible bias due to the change of diet. Unfortunately, this was impossible because of the slow wearing off of the effects of rhIGF-I after its discontinuation [17]. However, a major bias can be excluded since (1) the diet during the study was calculated on the basis of the dietary history of each patient, (2) the patients did not lose weight during the study, and (3) blood glucose [17] and lipid levels (this study) did not tend to decrease during the control period.

The most reasonable treatment for overweight Type 2 diabetic patients is diet and weight loss $[5,6]$. However, compliance is notoriously poor and sulphonylureas or insulin are added. Both agents decrease glucose and TG levels [7-10], but have only a small effect on C and Lp(a) levels [7-9], and may enhance hyperinsulinaemia [11]. The latter may even worsen the atherogenic risk $[3,6]$.

In conclusion, rhIGF-I treatment appears to improve the lipid profile of Type 2 diabetes. However, it is unknown whether increased IGF-I levels during prolonged rhIGF-I administration may by themselves affect atherogenesis in vivo. RhIGF-I was shown to stimulate retinal endothelial and aortic smooth muscle cell proliferation in vitro $[26,27]$. Hence, we need longer trials with careful monitoring of retinal and cardiovascular changes in order to find out whether the positive effects of rhIGF-I on lipid levels persist and how they relate to the overall cardiovascular risk.

Acknowledgements. We thank Dr. S.E.Jaeggi-Groisman, Ms A. Keller, Ms S. Graf, and Mr. A. Lenz for technical assistance and Dr. H.Drexel for $\mathrm{HDL}_{3}$-cholesterol and apolipoprotein determination. This work has been supported by the Swiss National Science Foundation (grant 31-9095.87) and by Ciba-Geigy AG, Basel.

\section{References}

1. Castelli WP (1984) Epidemiology of coronary heart disease: the Framingham study. Am J Med 76 [Suppl 2A]: 4-12 
2. Brand FN, Abbott RD, Kannel WB (1989) Diabetes, intermittent claudication, and risk of cardiovascular events. The Framingham Study. Diabetes 38: 504-509

3. Jarrett RJ (1988) Is insulin atherogenic? Diabetologia 31: 71-75

4. Seed M, Hoppichler F, Reaveley D et al. (1990) Relation of serum lipoprotein(a) concentration and apolipoprotein(a) phenotype to coronary heart disease in patients with familial hypercholesterolemia. N Engl J Med 322: 1494-1499

5. Henry RR, Wallace P, Olefsky JM (1986) Effects of weight loss on mechanisms of hyperglycemia in obese non-insulin-dependent diabetes mellitus. Diabetes 35:990-998

6. Barakat HA, Carpenter JW, McLendon VD et al. (1990) Influence of obesity, impaired glucose tolerance, and NIDDM on LDL structure and composition. Possible link between hyperinsulinemia and atherosclerosis. Diabetes 39: 1527-1533

7. Paisey R, Elkeles RS, Hambley J, Magill P (1978) The effects of chlorpropamide and insulin on serum lipids, lipoproteins and fractional triglyceride removal. Diabetologia 15: 81-85

8. Dunn FL, Raskin P, Bilheimer DW, Grundy SM (1984) The effect of diabetic control on very low-density lipoprotein-triglyceride metabolism in patients with type II diabetes mellitus and marked hypertriglyceridemia. Metabolism 33:117-123

9. Haffner SM, Tuttle KR, Rainwater DL (1992) Lack of change of lipoprotein(a) concentration with improved glycemic control in subjects with type II diabetes. Metabolism 41: 116-120

10. Taskinen MR, Belth WF, Harper I et al. (1986) The effects of noninsulin-dependent diabetes mellitus on VLDL triglyceride and VLDL apoB metabolism: studies before and after sulfonylurea therapy. Diabetes 35: 1268-1277

11. Firth R, Bell P, Marsh M, Rizza RA (1987) Effects of tolazamide and exogenous insulin on pattern of postprandial carbohydrate metabolism in patients with non-insulin-dependent diabetes mellitus. Results of randomized crossover trial. Diabetes 36: $1130-1138$

12. Zapf J, Schoenle E, Waldvogel M, Sand I, Froesch ER (1981) Effect of trypsin treatment of rat adipocytes on biological effects and binding of insulin and insulin-like growth factors. Further evidence for the action of insulin-like growth factors through the insulin receptor. Eur J Biochem 113: 605-609

13. Poggi C, Le Marchand-Brustel Y, Zapf J, Froesch ER, Freychet $P(1979)$ Effects and binding of insulin-like growth factor in the isolated soleus muscle of lean and obese mice: comparison with insulin. Endocrinology 195: 723-730

14. Caro JF, Poulos J, Ittoop O, Pories WJ, Flickinger EG, Sinha MK (1988) Insulin-like growth factor I binding in hepatocytes from human liver, human hepatoma, and normal, regenerating, and fetal liver. J Clin Invest 81: 976-981

15. Zenobi PD, Graf S, Thut A, Riesen W, Froesch ER (1991) Effects of recombinant human insulin-like growth factor-I (rhIGF-I) infusions on glucose and lipid metabolism in healthy man. Second International Meeting on Somatomedins/IGF's, San Francisco: D4 (Abstract)
16. Zenobi PD, Graf S, Ursprung.H, Froesch ER (1992) Effects of insulin-like growth factor-I on glucose tolerance, insulin levels, and insulin secretion in healthy man. J Clin Invest 89: 1908-1913

17. Zenobi PD, Jaeggi-Groisman SE, Riesen WF, Røder ME, Froesch ER (1992) Insulin-like growth factor-I improves glucose and lipid metabolism in type 2 diabetes mellitus. J Clin Invest 90: $2234-2241$

18. Warnick GR, Benderson JM, Albers JJ (1982) Quantitation of high-density lipoprotein subclasses after separation by dextran sulfate and $\mathrm{Mg}^{2+}$ precipitation. Clin Chem 28: 1574 (Abstract)

19. Greenfield M, Kolterman O, Olefsky J, Reaven GM (1980) Mechanism of hypertriglyceridaemia in diabetic patients with fasting hyperglycaemia. Diabetologia 18: 441-446

20. Jacob RJ, Sherwin RS, Bowen Let al. (1991) Metabolic effects of IGF-I and insulin in spontaneously diabetic BB/w rats. Am J Physiol 260: E262-E268

21. Simsolo RB, Ong JM, Saffari B, Kern PA (1992) LPL activity increased due to improved metabolic control. J Lipid Res 33:89-95

22. Brown MS, Dana SE, Goldstein JL (1974) Regulation of 3-hydroxy-3-methyl-glutaryl coenzyme A reductase activity in cultured human fibroblasts. J Biol Chem 249: 789-796

23. Miller NE, Hammett F, Saltissi S et al. (1981) Relation of angiographically defined coronary artery disease to plasma lipoprotein subfractions and apolipoproteins. Br Med J 282: 1741-1744

24. Armstrong VW, Schleef J, Thiery J et al. (1989) Effect of HELPLDL-apheresis on serum concentrations of human lipoprotein(a): kinetic analysis of the post-treatment return to baseline levels. Eur J Clin Invest 19: 235-240

25. Edén S, Bengtsson B-A, Oscarsson J, Wiklund O (1992) Growth hormone treatment of adults with growth hormone deficiency results in increases in lipoprotein(a) concentrations. Ninth International Congress of Endocrinology, Nice: 407 (Abstract)

26. Bornfeldt KE, Gidlöf RA, Wasteson A, Lake M, Skottner A, Arnqvist HJ (1991) Binding and biological effects of insulin, insulin analogues and insulin-like growth factors in rat aortic smooth muscle cells. Comparison of maximal growth promoting activities. Diabetologia 34: 307-313

27. Grant MB, Guay C, Marsh R (1990) Insulin-like growth factor I stimulates proliferation, migration, and plasminogen activator release by human retinal epithelial cells. Curr Eye Res 9:323-335

Received: 27 October 1992

and in revised form: 14 January 1993

Dr. P.D.Zenobi

Division of Endocrinology and Metabolism

Department of Internal Medicine

University Hospital

Rämistrasse 100

CH-8091 Zurich

Switzerland 